\title{
Everybody who deals with ciliates knows him. Professor Wilhelm Foissner (18.08.1948-20.03.2020)
}

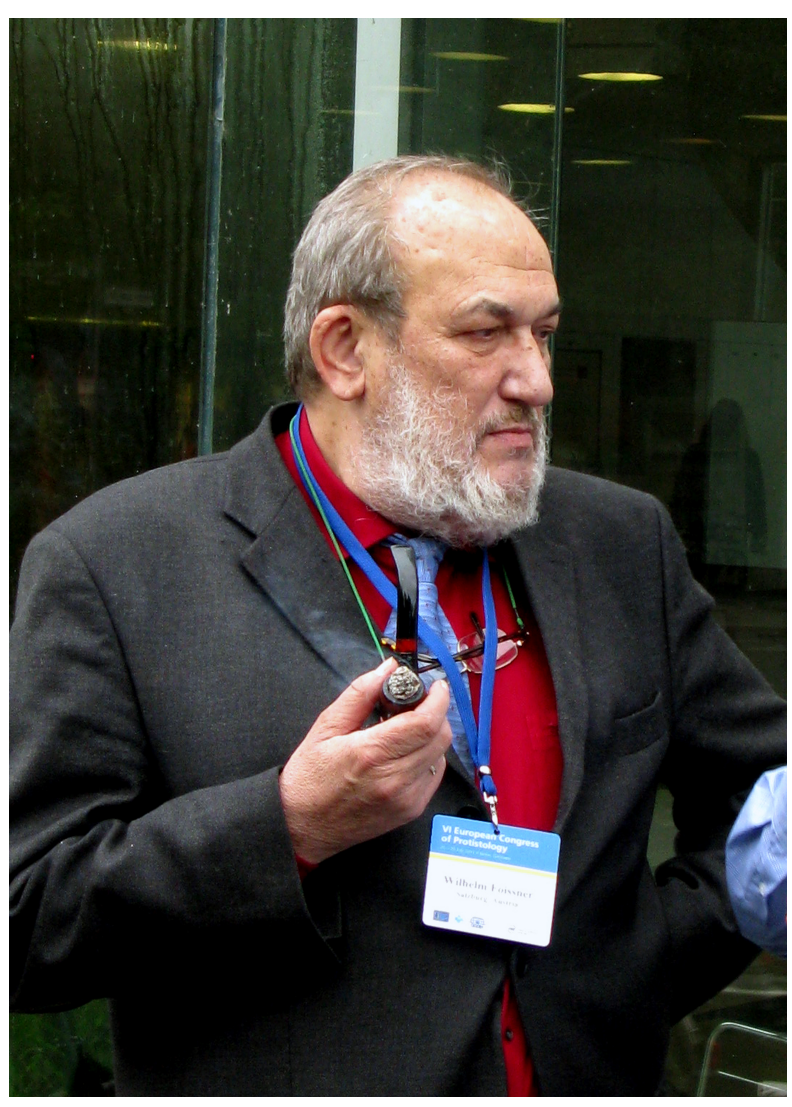

Prof. W. Foissner. VI European Congress of Protistology. Berlin, Germany, 2011.

On March 20, 2020, Wilhelm Foissner, a world-renowned protistologist and expert in ciliates, a retired professor of the local university, died in Salzburg, Austria; he was 71 years old. For several recent years, he was consistently resisting the long-standing health problems. Despite the obvious nature of these problems - his blood vessels' tendency to form aneurysms - the denouement has come so unexpectedly and prematurely... In the beginning of March, Prof. Foissner spoke at the Annual Meeting of the German Society for
Protozoologists in Kaiserslautarn, Germany, and the situation looked not so bad. My colleague, Dr. R. Radek wrote to me: "He was extremely interested in the talks and debates and discussed a lot. It was truly a shock to learn that he died so unexpectedly. But he himself knew about his risks" 1

Wilhelm (Willi) Foissner was not only a great protistologist-ciliatologist; he was a living legend. Professor is no longer with us, but he remains in our hearts and minds and will continue to be a legendary person for the generations of those fascinated by ciliated protists.

His early years did not promise such an excellent scientific carrier. Wilhelm was born in the Village of Wartberg ob der Aist, Upper Austria, in the family of a railway worker and a housewife, Anton and Maria Foissners. After graduating from a basic school in 1962, Willi became a carpenter apprentice in the city of Linz and finished his studies with a fellow degree in 1967.

However, after military service (one year) he got the Higher School Certificate having passed the school exam externally aiming to change his field of study to biology at the Salzburg University (1973). In fact, while still at the basic school, the boy bought his own microscope for studying the invisible world of protists. Foissner also succeeded to make acquaintance with an Austrian amateur ciliatologist Bruno M. Klein (1891-1968). Even though they communicated during only a couple of years (1966-1968), Foissner can be considered Klein's disciple. During our conversation in 2006 at the VII Asian Conference on Ciliate Biology Willi cordially remembered Bruno exactly this way - as his teacher. Moreover, in 1967-1972 one of the first areas of investigation, which Foissner had started, was the silverline system of ciliates - application of

${ }^{1}$ I am sincerely grateful to Dr. R. Radek and Prof. K. Hausmann for useful information and to Prof. K. Hausmann for the photo of W. Foissner in Salzburg University. 


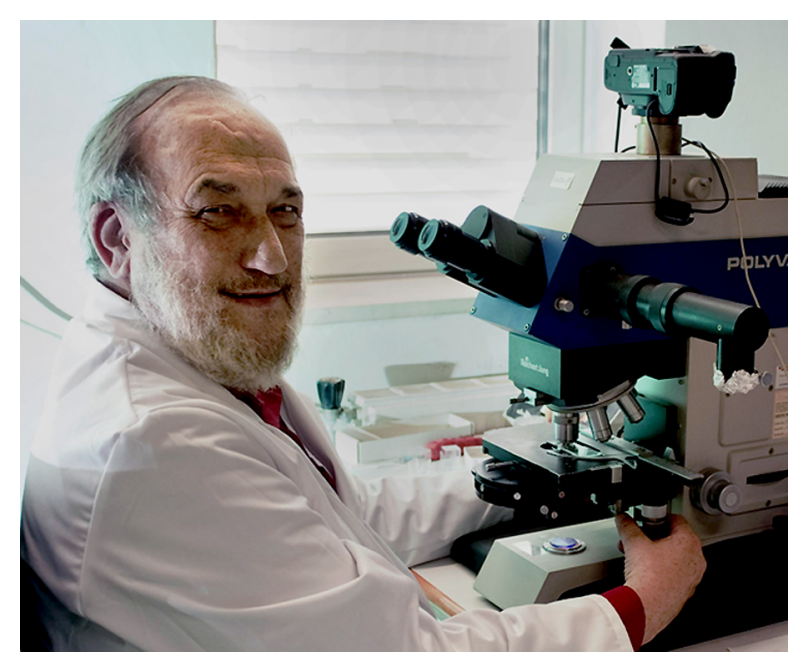

Prof. W. Foissner at his favorite "Polyvar" (Reichert-Jung microscope). Salzburg, 2016.

Klein's method of dry silver staining. At that time Willi had not even entered the university and worked as a laboratory assistant and then as a teacher at the medical school in the hospital of Linz, where he was responsible for microscopy and photography.

Having studied first zoology and botany at the University, in 1979 Foissner completed his education by defending his protozoological $\mathrm{PhD}$ thesis. This was an unusually voluminous work entitled "Hydrobiological Study in Shallow Waters of the High Alps, with special attention to ciliates (Protozoa, Ciliophora)", which consisted of 2 parts. Part I - Physical and chemical research and ecology of ciliates - 175 pages; part II - Taxonomy and systematics of ciliates -411 pages! This was already an indication of the high research potential and an exclusive efficiency of the author. Indeed, in three years Dr. Foissner already made his habilitation and switched to another field of research - ciliated protists in saprobe system, and the terrestrial ciliates - for a long time his main subject - representatives of the class Colpodea, Ciliophora (Foissner, 1993).

Having been an assistant in the Institute for Zoology at the University of Salzburg (1980-1986) and then an extraordinary Professor (Extraordinarius) of Zoology there (1987-2017), Prof. Dr. Foissner conducted during 40 years a truly amazing scientific activity: in total close to 770 publications, including 15 voluminous monographs, more than 40 chapters in books, more than 430 articles in journals and about 255 abstracts of communications, totaling over 17,000 printed pages! In the obituary published at the homepage of the Berlin Microscopical Society, Prof. K. Hausmann stressed: "I do not know any colleagues who would have at least about such

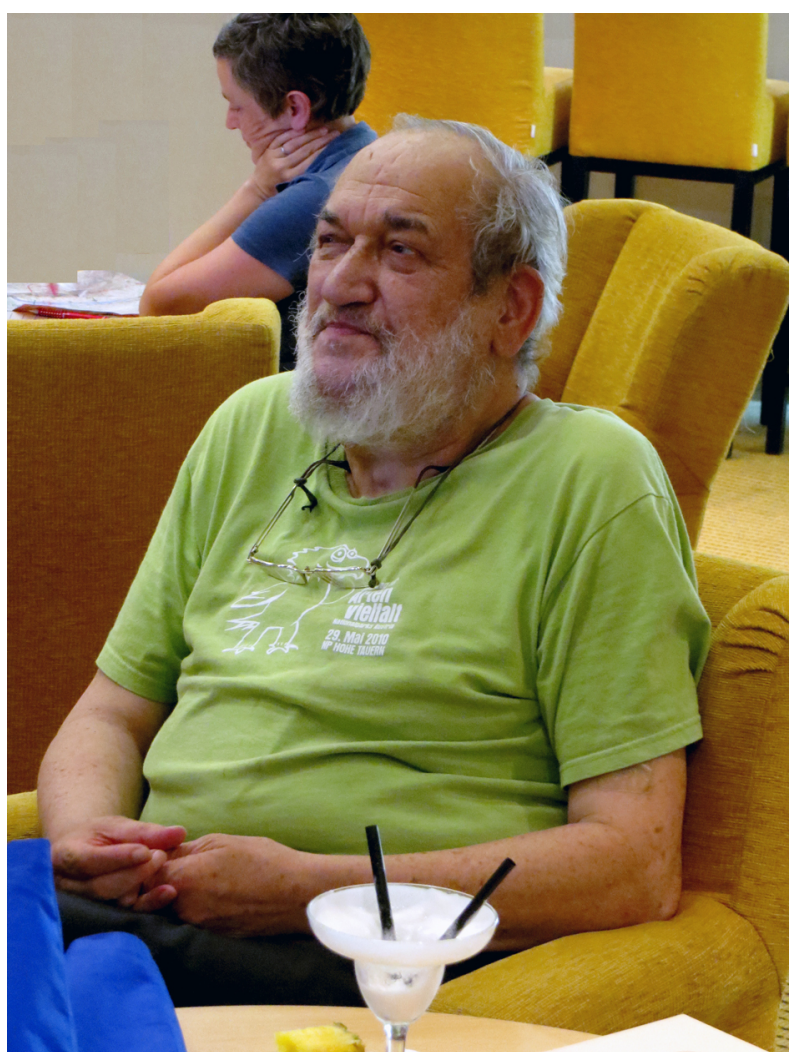

Coffee-break at the XV International Congress for Protistology. In the background Dr. B. Sonntag. Prague, the Czech Republic, 2017.

a collection of works. This incredible amount involved exceptionally high quality, especially with respect to illustrations in Foissner's publications". Indeed, during his active scientific life Prof. Foissner succeeded to cover such different fields as methodology, theory, ecology, history, popular writing, phylogeny, and taxonomy (Aescht and Berger, 2008). He was proactive until the very end of his life and with his co-workers conducted a number of fundamental studies of biogeography, ecology, faunistics, limnology, molecular biology, nomenclature, saprobiology, soil biology, systematics, and ultrastructure of ciliated protists ${ }^{2}$. Around 600 new ciliate species were described by W. Foissner and his colleagues. They also made close to 3400 redescriptions and taxa reviews in this group of protists.

Prof. Foissner was a tireless traveler. His trips to various rather exotic places of our planet have significantly enriched materials on biodiversity and

${ }^{2}$ For the references you can have a look at "The Wilhelm Foissner Festschrift" (Denisia 23, 2008) as well as at Prof. Foissner's website, which is still available at http://www. wfoissner.at. 


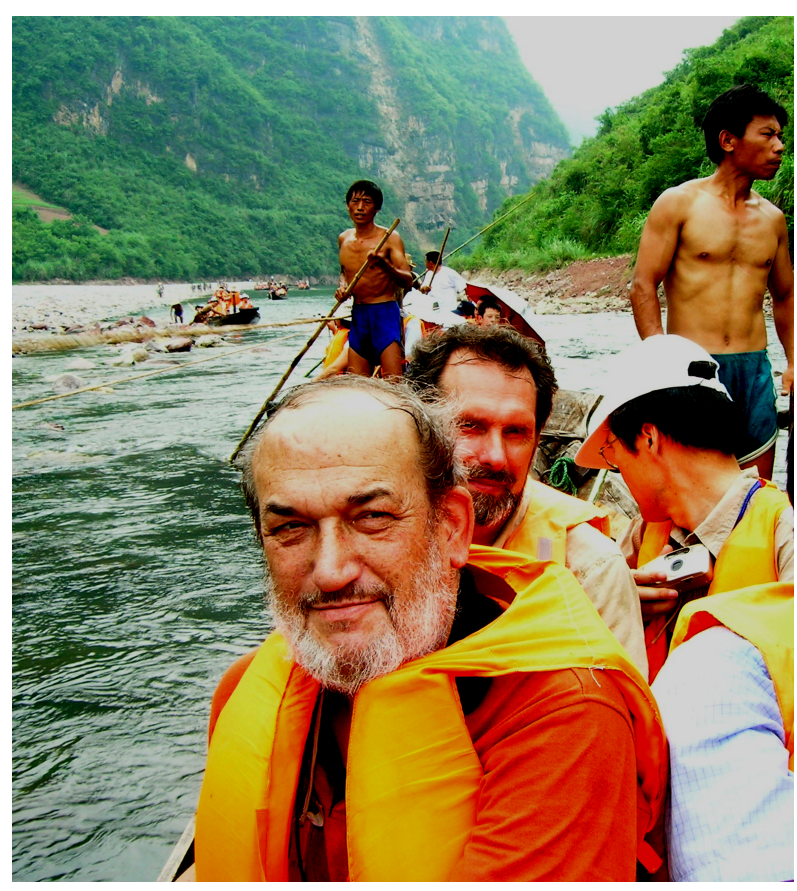

Prof W. Foissner and Dr. S.I. Fokin during a journey along a tributary of the Yangtze River. China, 2006 (after the VII Asian Conference on Ciliate Biology).

level of endemism among ciliates. Kenya, Costa Rica, Brazil, Peru, Chile, Australia, Tasmania, Botswana and some other countries - those are the places where Foissner collected his samples. Territories close to Arctic or Antarctic habitats did not attract the scientist: "Too cold" - he said.

Like many people who are fully immersed in their job, Prof. Foissner was not an "easy" man - I have known him personally for almost 30 years and talked to him several times tête-à-tête, but I cannot say that I really knew him well. One day (in the mid-1990ies), I came to his place in Salzburg from Stuttgart, Germany, specifically to discuss a particular issue of the Paramecium systematics. After a short welcome conversation and a light breakfast (I arrived in the morning), Willi showed me his simple and quite small house. He led me into a large room, which was completely full of book shelves with books, magazines and reprints of articles dedicated to ciliates and other protists. Not without pride, he said: "There are several Mercedes cars here" (referring to the cost of the collection). His wife, now unfortunately a widow, Prof. Ilse Foissner (Fuchs) is also the biologist (botanist). So let us hope these treasures will be kept. Since the same day Willi was working also with another

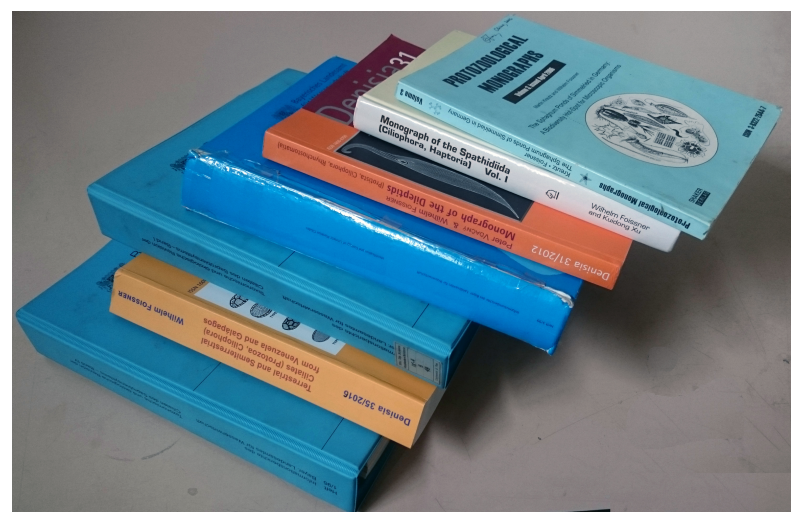

Books by Prof. Foissner and colleagues are always in use. The protistological laboratory, Pisa University, Italy, 2020.

colleague - Dr. K. Al-Rashid, I was given a bike and spent half a day just riding around Salzburg. Thus, I became acquainted with this wonderful city for the first time with Foissner's help.

Prof. Foissner writings should definitely be recognized as exceptional in value and scope of their subjects. His efficiency was just phenomenal, and the quality of publications was always the highest. He wrote to me in 2017: "I am now retired and have to leave the University, but I shall create a "private laboratory" because I still have materials for many publications. Presently, I am working on a monograph on terrestrial ciliates from Australia"'

Moreover, Prof. Dr. Foissner was a very active member of the world scientific community. He participated as a member of board of reviewers in all protistological and related international journals. Professor founded and was the Chief Editor of the series "Protozoological Monographs". The Foundation "Wilhelm and Ilse Foissner Stiftung" was promoting German-speaking young protozoologists in alpha-taxonomy. Prof. Foissner was elected as the President of the German Society for Protozoology (1996) and the President of the International Society of Protistologists (2006); he received a number of awards and honors.

In general, every person is unique, but people like Prof. Foissner come to this world not so often. Before him, of a similar caliber was Alfred Kahl (1877-1946) in Germany of the 1920-1940ies, and prior to him in 1875-1890ies - Otto Bütschli (1848 -1920 ) in the same country. There is no doubt that Wilhelm Foissner has already taken a well-deserved

${ }^{3}$ It looks like this job was not completed. 
place in this historical row - a number of scientists who have drawn up the glory of Protistology. Professor had no children, his entire soul and all his knowledge Foissner has put into his studies and, finally, articles and books about ciliates. Through them he will continue to live and serve Science and people engaged in it - all of us, colleagues of Prof. Wilhelm Foissner, as well as many following generations of protistologists. This connection did not break with his death; and it will not be interrupted in the future!

\section{References}

Aescht E. and Berger H. 2008. Univ.-Prof. Dr. Wilhelm Foissner - 60 years: biographical sketch and bibliography. Denisia. 23, 15-46.

Foissner W. 1993. Colpodea (Ciliophora). Protozoenfauna. 4/1, 1-798.

Sergei I. Fokin. Department of Biology, Protistology-Zoology Unit, University of Pisa, 56126, Pisa, Italy; St. Petersburg Branch of the S.I. Vavilov Institute of History of Science and Technology Russian Academy of Sciences, and St. Petersburg State University, 199034, St. Petersburg, Russia; e-mail: sifokin@mail.ru 